\title{
Knowledge and practice of colorectal cancer screening in an urban setting: cross-sectional survey of primary care physicians in government clinics in Malaysia
}

\author{
Chor Yau $\underline{\mathrm{Oo}}^{1}$, MD, Nik Sherina $\underline{\text { Hanafi }}^{2}$, PhD, Su May Liew ${ }^{2}$, DPhil(Oxon)
}

\begin{abstract}
INTRODUCTION Colorectal cancer (CRC) was the third most commonly diagnosed cancer worldwide in 2008 (1.23 million cases, $9.7 \%$ ). CRC screening was shown to be effective in reducing $70 \%$ of $C R C$ mortality. However, the screening rate for $\mathrm{CRC}$ remains poor.

METHODS A cross-sectional survey was conducted among primary care physicians (PCPs) in public primary care clinics in Kuala Lumpur, Malaysia. A 30-item self-administered questionnaire was used to assess the knowledge and practice of CRC screening.

RESULTS The response rate was $86.4 \%(n=197 / 228)$. Less than half $(39.1 \%)$ of the respondents answered correctly for all risk stratification scenarios. Mean knowledge score on CRC screening modalities was $48.7 \% \pm 17.7 \%$. The knowledge score was positively associated with having postgraduate educational qualification and usage of screening guidelines. Overall, $69.9 \%$ of PCPs reported that they practised screening. However, of these, only $25.9 \%$ of PCPs screened over $50 \%$ of all eligible patients. PCPs who agreed that screening was cost-effective (odds ratio [OR] 3.34, $95 \%$ confidence interval [ $\mathrm{Cl}$ ] 1.69-6.59) and those who agreed that they had adequate resources in their locality (OR 1.92, 95\% Cl 1.01-3.68) were more likely to practise screening. Knowledge score was not associated with the practice of screening $(p=0.185)$.

CONCLUSION Knowledge and practice of CRC screening was inadequate among PCPs. Knowledge of screening did not translate into its practice. PCPs' perceptions about cost-effectiveness of screening and adequate resources were important determinants of the practice of screening.
\end{abstract}

Keywords: colorectal cancer screening, knowledge, practice, primary care physicians

\section{INTRODUCTION}

Over a million cases of colorectal cancer (CRC) are diagnosed annually worldwide. In terms of mortality, CRC causes more than 600,000 deaths annually. It was the third most commonly diagnosed cancer worldwide in 2008 (1.23 million cases, 9.7\%), and is the second most common cancer in women and the third most common cancer in men. ${ }^{(1)}$ In Malaysia, CRC is the second most common cancer, with an incidence of $13.2 \%$, and the most common cancer among men (16.3\%). ${ }^{(2)}$

CRC screening has been shown to be effective in reducing associated mortality and incidence. This is because the pathogenesis of CRC is well established. It has long been known that CRC arises from premalignant adenomatous polyps. ${ }^{(3)}$ Therefore, the strategy for CRC screening is to detect early adenomatous polyps or early-stage adenocarcinoma for removal..$^{(4)} \mathrm{A}$ large prospective study carried out in Japan reported a $70 \%$ reduction in CRC mortality with screening. ${ }^{(5)}$ Similarly in the United States, there has been a steadily declining rate of CRC incidence due to extensive screening. ${ }^{(6)}$

Yet uptake of CRC screening remains low. A large multicentre study in Asia reported that countries in Southeast Asia had very low rates of CRC screening - Singapore (20.3\%), Brunei $(8.8 \%)$, Indonesia (1.5\%) and Thailand (18.8\%). ${ }^{(7)}$ In this study, only $1.2 \%$ of Malaysian respondents were found to have been screened. ${ }^{(7)}$ In the United States, the screening rate was about $50 \%$. ${ }^{(8)}$

Malaysia practises a two-tier healthcare system, which includes the government and private sectors. In the government healthcare system, which is the focus of this study, CRC screening tests are available in hospitals and selected health clinics. Patients can be screened at minimal cost using the faecal occult blood test (FOBT) in health clinics and colonoscopy in tertiary hospitals. However, currently, there is no population-based CRC screening programme being implemented in Malaysia. ${ }^{(9,10)}$

Primary care physicians (PCPs) play a very important role in CRC screening. Many studies have shown that PCP recommendation is a strong predictor of screening participation by patients. ${ }^{(7,11,12)} \mathrm{A}$ local study reported that $84.6 \%$ of patients would undergo screening if advised to do so by their primary care providers. ${ }^{(12)}$ The aim of this study was to improve screening rates for CRC by assessing the current level of knowledge and practice of CRC screening among PCPs in Malaysia.

\section{METHODS}

This was a cross-sectional questionnaire survey conducted from July to August 2014. All eligible PCPs working in public clinics in Kuala Lumpur, Malaysia, during the study period were invited

${ }^{1}$ Department of Family Medicine, Faculty of Medicine and Health Sciences, Universiti Malaysia Sarawak, Sarawak, ${ }^{2}$ University of Malaya Primary Care Research Group, Department of Primary Care Medicine, Faculty of Medicine, University of Malaya, Kuala Lumpur, Malaysia

Correspondence: Dr Chor Yau Ooi, Lecturer, Department of Family Medicine, Faculty of Medicine and Health Sciences, Universiti Malaysia Sarawak, 94300 Kota Samarahan Sarawak, Malaysia.cyooi@unimas.my 
to participate in the study. There were 13 government clinics and two academic primary care clinics in this geographical location.

The questionnaire for the study was adapted from three studies - two from the United States and another from Canada. ${ }^{(13-15)}$ Some items were adapted from recommendations by the Singapore Ministry of Health Clinical Practice Guidelines for Cancer Screening 2010. ${ }^{(16)}$ The questionnaire was divided into five sections (Sections A-E): demographic data and place of practice; risk stratification of CRC; knowledge on CRC screening modalities; practice of CRC screening; and perceived barriers and facilitators influencing decision-making on CRC screening (Appendix).

Section A pertained to the participant's gender, age, ethnicity, postgraduate educational qualifications, years of practice, daily patient attendance, place of practice and usage of guidelines.

Section B was regarding risk stratification of CRC. Four clinical scenarios were given to the participant to risk stratify the patient into each scenario: scenario 1 (patient, aged 62 years, with history of inflammatory bowel disease); Scenario 2 (patient, aged 60 years, with family history of $\mathrm{CRC}$ in two relatives [one at age 45 years, another at age 50 years]); Scenario 3 (female, aged 60 years, no family history of CRC); and Scenario 4 (male, aged 60 years, no family history of CRC). For each scenario, participants were asked to categorise the patient as 'low risk', 'average risk', 'high risk' or 'don't know'.

Section C was regarding knowledge on CRC screening modalities. There were two parts to this section. The first part assessed the participant's knowledge on CRC screening for average-risk patients. Areas that were assessed were recommended test, starting age and recommended frequency. The screening tests assessed were FOBT, colonoscopy, double-contrast barium enema, flexible sigmoidoscopy and serum carcinoembryonic antigen. The second part assessed the participant's knowledge on CRC screening for high-risk patients. Participants were assessed on which conditions needed to be screened, recommended age at which to start offering screening, recommended frequency and recommended test for each condition. Patients were assessed for a family history of familial adenomatous polyposis, family history of hereditary non-polyposis colorectal cancer and history of inflammatory bowel disease.

Section D was regarding the practice of CRC screening. Participants were asked if they practised CRC screening, as well as the starting age for screening, proportion of eligible patients screened and screening test used in practice.

Section E concerned perceived barriers and facilitators influencing the decision for CRC screening. Participants were given six statements pertaining to CRC screening. The response was recorded in a Likert scale, ranging from 'strongly agree' and 'agree' to 'disagree', 'strongly disagree' and 'not sure'.

The questionnaire underwent face and content validations by an expert panel comprising two primary care specialists - a gastroenterologist and a colorectal cancer surgeon. The draft study was piloted on ten PCPs from an academic primary care clinic, following which minor changes were made to produce the final version of the questionnaire. The estimated time needed to complete the questionnaire was 10-15 minutes.

All clinics were visited by the principal investigator at the start of the study. A medical officer in charge of the clinic coordinated the data collection. This representative was briefed in detail and face-to-face about the study. Informed consent was collected by the representative, who also distributed and collected the research forms (i.e. participant information sheet, consent form and questionnaire). The questionnaires and consent forms were then returned to the researcher.

Data was analysed using IBM SPSS Statistics version 20.0 (IBM Corp, Armonk, NY, USA). Data was summarised as mean and percentage values. The knowledge score was calculated based on responses received in Section C. For calculation of the knowledge score, a score of 1 was awarded for every correct response and no score was given for wrong or empty response. There was no negative marking. In the column for screening test for high-risk patients, no score was awarded if one of the choices ticked was a wrong response. This was to avoid any bias, as participants were given the option to tick multiple choices for this column. The minimum score possible was 0 and maximum score was 30 . Logistic regression analysis using forward elimination was used to identify predictors of the practice of CRC screening.

This study was approved by the University Malaya Medical Centre Ethics Committee (reference no. 1045.8) and Ministry of Health Malaysia Medical Research and Ethics Committee (reference no. NMRR-13-1589-14913).

\section{RESULTS}

The response rate was $86.4 \%$ (197/228 participants). The characteristics of the participants are shown in Table I. About three-quarters $(78.2 \%)$ of the participants were women. A majority of participants were of Malay ethnicity (57.9\%) and only one in five $(21.6 \%)$ participants had postgraduate educational qualifications. A third (33.7\%) of the participants did not use any form of guidelines for CRC screening. When used, international guidelines for CRC screening were referred to more commonly (91.9\%) than local guidelines (8.1\%).

In Section B, only $39.1 \%$ of PCPs risk stratified all four scenarios correctly, followed by $22.3 \%$ who risk stratified three scenarios correctly. Another $25.9 \%$ of PCPs risk stratified two scenarios correctly, while $11.7 \%$ risk stratified only one scenario correctly, and 2 (1.0\%) participants responded wrongly to all four scenarios. Of these, one PCP answered 'don't know' for all four scenarios. Among the scenarios that were correctly stratified, Scenario 3 received the lowest number of correct responses (47.0\%), followed by Scenario 4 (70.0\%) and Scenario 1 (75.0\%). Scenario 2 received the highest rate of correct responses (95.0\%).

Concerning the knowledge of PCPs on CRC screening modalities, for average-risk patients, most (90.4\%) PCPs correctly recommended FOBT as a screening modality. Doublecontrast barium enema and serum carcinoembryonic antigen were recommended by $17.9 \%$ and $18.8 \%$ of PCPs, respectively, even though these tests are not recommended in the guidelines. A majority could correctly identify the starting age for screening. 
Table I. Characteristics of participants $(n=197)$.

\begin{tabular}{|ll|}
\hline Characteristic & No. (\%) \\
\hline Gender & $43(21.8)$ \\
\hline Male & $154(78.2)$ \\
\hline Female & $35.4 \pm 7.6(26.0-64.0)$ \\
\hline Age* (yr) & $114(57.9)$ \\
\hline Ethnicity & $50(25.4)$ \\
\hline Malay & $27(13.7)$ \\
\hline Indian & $6(3.0)$ \\
\hline Chinese & $42(21.6)$ \\
\hline Other & $152(78.4)$ \\
\hline Postgraduate educational qualifications \\
\hline Yes & $6.6 \pm 6.8(1.0-37.0)$ \\
\hline No & \\
\hline Duration of practice* $(\mathbf{y r})$ & $126(66.3)$ \\
\hline Use of guidelines & \\
\hline Yes & $64(33.7)$ \\
\hline No & \\
\hline No. of patients seen daily & $29(14.7)$ \\
\hline$\leq 20$ & $74(37.6)$ \\
\hline $21-40$ & $51(25.9)$ \\
\hline $41-60$ & $27(13.7)$ \\
\hline $61-80$ & $14(7.1)$ \\
\hline $81-100$ & $2(1.0)$ \\
\hline$>100$ & \\
\hline Data & \\
\hline
\end{tabular}

*Data presented as mean \pm standard deviation (range). + Missing data from three participants. ¥Missing data from seven participants.

Table II. Practices with respect to colorectal cancer screening.

\begin{tabular}{|ll|}
\hline Variable & No. (\%) \\
\hline Practises screening $(\mathbf{n}=\mathbf{1 9 6})$ & $137(69.9)$ \\
\hline Yes & $59(30.1)$ \\
\hline No & $50.1 \pm 6.0(20.0-60.0)$ \\
\hline $\begin{array}{l}\text { Age of patient at which to start } \\
\text { offering screening* }(\mathbf{y r})\end{array}$ \\
\hline $\begin{array}{l}\text { Proportion of eligible patients } \\
\text { screened ( } \mathbf{n}=135)\end{array}$ \\
\hline$\leq 25 \%$ & $65(48.1)$ \\
\hline $26 \%-49 \%$ & $35(25.9)$ \\
\hline $50 \%-74 \%$ & $28(20.7)$ \\
\hline$\geq 75 \%$ & $7(5.2)$ \\
\hline
\end{tabular}

*Data presented as mean \pm standard deviation (range).

For high-risk patients, a high percentage of PCPs correctly recommended screening for patients with family history of familial adenomatous polyposis (95.4\%), hereditary non-polyposis colorectal cancer $(92.7 \%)$ and patients with inflammatory bowel disease (88.6\%). Almost half of the PCPs recommended FOBT as a screening test although it is not recommended for any of the three conditions mentioned above.

As for the frequency of screening, only about $60.0 \%$ of PCPs gave the right recommendation for familial adenomatous polyposis and hereditary non-polyposis colorectal cancer. For inflammatory bowel disease, only $48.8 \%$ of PCPs recommended screening according to guidelines. However, a majority could not identify correctly the age at which to start offering screening.

In terms of CRC screening modalities, PCPs had a mean knowledge score of $14.60 \pm 5.32(48.7 \% \pm 17.7 \%)$ out of a maximum possible score of $30(100.0 \%)$. The lowest score recorded was $0(0 \%)$ and the highest score was 28 (93.3\%). When a general linear model was used to determine independent predictors that significantly affect the knowledge score, we found that usage of guidelines $(p=0.02)$ and postgraduate educational qualifications $(p<0.001)$ were significantly associated with the knowledge score of PCPs.

Overall, $69.9 \%$ of PCPs reported that they practised CRC screening for average-risk patients (Table II). However, the proportion of patients being screened was low, as more than half (74.0\%) of our PCPs screened less than $50 \%$ of eligible patients. Regarding the starting age for screening, $66.7 \%$ of PCPs reported starting screening at 50 years, $10.4 \%$ at 40 years and $14.1 \%$ at 60 years. Screening modalities that were most often used were FOBT $(94.0 \%)$, followed by colonoscopy $(61.0 \%)$ and serum carcinoembryonic antigen (12.0\%).

With regard to the perceived barriers and facilitators influencing the decision on CRC screening among PCPs, most PCPs perceived that they lacked knowledge about screening tests $(55.9 \%)$ and recommendations for screening were inconsistent between the various guidelines (55.4\%). However, two-thirds (74\%) of PCPs felt that screening was cost-effective. A majority $(94.4 \%)$ of PCPs perceived that screening was beneficial for their patients.

Concerning factors influencing PCPs to screen patients for CRC, univariate logistic regression analysis showed that knowledge was significantly associated with the practice of CRC screening (Table III). Those who practised CRC screening had higher knowledge scores when compared to those who did not $(p=0.033)$. PCPs who perceived screening as being cost-effective and those who had adequate resources for screening were more likely to practise screening. On multivariate logistic regression analysis, however, knowledge did not remain as a significant predictor. Perception of screening as being cost-effective (odds ratio $[\mathrm{OR}] 3.3,95 \%$ confidence interval $[\mathrm{Cl}] 1.7-6.6)$ or having adequate resources to do screening ( $\mathrm{OR} 1.9,95 \% \mathrm{Cl} 1.0-3.7$ ) remained significantly associated with the practice of CRC screening.

\section{DISCUSSION}

In our study, only one-third (39.1\%) of PCPs were able to correctly risk stratify patients for all four scenarios presented for CRC risk stratification. Mean knowledge score on CRC screening modalities was $48.7 \% \pm 17.7 \%$. Knowledge score was positively associated with having a postgraduate educational qualification and the usage of guidelines for CRC screening. Although nearly $69.9 \%$ of PCPs reported that they practised CRC screening, only $25.9 \%$ of them screened over half of all eligible patients. The commonly used CRC screening tools were FOBT and colonoscopy. Serum carcinoembryonic antigen was also used although it is not 
Table III. Results of logistic regression analysis of factors influencing the practice of screening.

\begin{tabular}{|c|c|c|c|c|c|}
\hline \multirow[t]{2}{*}{ Factor } & \multirow{2}{*}{$\begin{array}{l}\text { Practises screening } \\
\text { (no. [\%]) }\end{array}$} & \multicolumn{2}{|c|}{ Univariate } & \multicolumn{2}{|l|}{ Multivariate } \\
\hline & & Crude OR (95\% CI) & p-value & Adjusted OR (95\% CI) & p-value \\
\hline Knowledge score on screening (mean \pm SD) & $15.12 \pm 5.14$ & - & $0.033^{*}$ & $0.96(0.90-1.02)$ & 0.185 \\
\hline \multicolumn{6}{|l|}{ Cost-effective } \\
\hline Disagree & $25 / 51(49.0)$ & 1 & $<0.001^{*}$ & 1 & $0.001^{*}$ \\
\hline Agree & $111 / 144(77.1)$ & $3.50(1.79-6.85)$ & & $3.34(1.69-6.59)$ & \\
\hline \multicolumn{6}{|l|}{ Beneficial for patients } \\
\hline Disagree & 4/11 (36.4) & 1 & $0.013^{*}$ & 1 & 0.134 \\
\hline Agree & 132/184 (71.7) & $4.44(1.25-15.81)$ & & $2.79(0.73-10.64)$ & \\
\hline \multicolumn{6}{|l|}{ Adequate resources in the region } \\
\hline Disagree & $61 / 98(62.2)$ & 1 & $0.022^{*}$ & 1 & $0.048^{*}$ \\
\hline Agree & 75/97 (77.3) & $2.07(1.11-3.87)$ & & $1.92(1.01-3.68)$ & \\
\hline
\end{tabular}

${ }^{*} \mathrm{p}<0.05$ is statistically significant. $\mathrm{Cl}$ : confidence interval; OR: odds ratio; SD: standard deviation

recommended as a screening test in the guidelines. PCPs who agreed that screening was cost-effective and those who had enough resources in their locality were more likely to practise CRC screening.

With only $39.1 \%$ of PCPs being able to risk stratify all four scenarios correctly, the proportion of PCPs who were able to do this in our study was much lower than that in another study, where $72.7 \%$ of participants could respond correctly to all four scenarios. ${ }^{(15)}$ Accurate risk stratification is important for PCPs to be able to provide the appropriate screening recommendation. A lower percentage of PCPs being able to risk stratify correctly is an area of concern, as the likelihood of them offering wrong advice or recommendations vis-à-vis CRC screening could, accordingly, be expected to be high. This could be due to CRC screening not being widely practised by PCPs, and thus their knowledge of risk stratification was lacking.

Most PCPs were able to give the right screening recommendations for average-risk patients. For high-risk patients, most PCPs correctly recommended screening for all three categories. However, most of the recommendations given were not guideline-consistent. FOBT was recommended by almost half of all PCPs although it is not recommended in the guidelines. This is a source of concern, as it points to wastage of resources due to inappropriate screening. Generally, this reflects a lack of knowledge among PCPs on screening for high-risk patients. A study done in the United States reported that PCPs had poorer knowledge, as compared to gastroenterologists, when it came to CRC screening for high-risk patients. ${ }^{(17)}$ This could be due to a lack of exposure to these patient groups among PCPs, as most of such patients tend to be diagnosed by gastroenterologists. It is also likely that follow-up screenings for these patients would have been done by gastroenterologists.

The overall knowledge score was $48.7 \% \pm 17.7 \%$ in our study, and PCPs with postgraduate educational qualifications and those using guidelines received significantly higher scores. These results were consistent with other studies that have shown that PCPs who adhered to guidelines and had training were more likely to give guideline-consistent screening recommendations. ${ }^{(18-20)} \mathrm{A}$ study in the United States that assessed knowledge of physicians on CRC screening in high-risk populations found that being unaware of screening guidelines was associated with significantly lower knowledge scores. ${ }^{(19)}$ In a study from Italy, no association was found between knowledge score and gender, age, ethnicity and years of practice of physicians. ${ }^{(20)}$

In our study, $69.9 \%$ of PCPs practised CRC screening for their patients. In comparison, in the United States, almost $99 \%$ of PCPs practised CRC screening, while in Italy, about $80 \%$ of physicians practised the same. ${ }^{(20,21)}$ Overall, the rate of screening was low in our study when compared to other countries. Even though our PCPs reportedly practised screening, not many patients were actually screened, with only $25.9 \%$ of PCPs screening more than $50 \%$ of eligible patients for CRC. Another Malaysian study found that only about $21 \%$ of healthcare providers screened more than $50 \%$ of their patients with FOBT. ${ }^{(22)}$ One reason for this could be a lack of concerted effort on the dissemination of best practices for CRC screening, and of providing clear screening and follow-up guidelines to primary care providers. The consensus published by the Academy of Medicine Malaysia needs to be updated and highlighted to PCPs in order to improve the practice of CRC screening in the country. ${ }^{(23)}$ Another possible reason for this finding could be that PCPs had overstated their practice in our survey.

PCPs who agreed that screening was cost-effective were more likely to practise CRC screening. This outcome was consistent with a similar study in Canada, where physicians who agreed that screening was cost-effective were 3.4 times more likely to practise screening. ${ }^{(14)}$ A study that looked into factors associated with the practice of screening among PCPs in Hong Kong reported that cost was a major reason for not screening $(62.4 \%) .{ }^{(24)}$ To the contrary, a study in the United States had shown that CRC screening was, in fact, cost-effective. This study found that offering screening to patients aged 50 years and above would result in a gain of USD 11,900 per year of life. ${ }^{(25)}$ Therefore, educating PCPs on the cost-effectiveness of CRC screening may increase the practice of screening. Nevertheless, the cost of screening may be variable in different countries and in different health systems. Therefore, this matter warrants consideration prior to educating PCPs on the cost-effectiveness of CRC screening in various countries. 
PCPs who agreed that there were adequate resources for screening in their locality were more likely to practise CRC screening. In Malaysia, the unavailability of screening kits was cited as a major barrier to screening. ${ }^{(22)}$ Currently, only selected government clinics have laboratory facilities and not all have FOBT kits. Only the larger hospitals and clinics selected for the CRC screening programme have screening tests at hand. Colonoscopy is only available in hospitals where there are gastroenterologists and surgeons who can perform the procedure. Most of the time, these practitioners are overwhelmed by the many referrals received and waiting times can be long, ranging from six months to one year. Therefore, increasing the resources available for screening is necessary to encourage more PCPs to practise CRC screening.

Another outcome observed in the present study was that the knowledge score of PCPs was not associated with the practice of screening. No significant association was found between knowledge score and screening practice after adjusting for confounders $(p=0.185)$. In fact, a study in Italy showed that $10 \%$ of physicians who had very high knowledge score did not practise screening. ${ }^{(20)}$ Knowledge is important for ensuring that the screening done is consistent with guideline recommendations. However, just having knowledge may not be sufficient. A positive attitude towards screening is an important factor in the practice of screening, as reported by a study from Hong Kong, which found that PCPs with a positive attitude towards screening were two times more likely to practise screening. ${ }^{(24)}$

Our study was not without strengths and limitations. One of the strengths was the good response rate achieved among PCPs. The outcomes from this study have provided insights on the knowledge and current practices of CRC screening among PCPs in Malaysia. However, as this was a cross-sectional study, it only measured responses of PCPs at a certain point in time. This may not accurately reflect their actual medical practice. Another limitation was that this was a self-reporting survey and no comparisons were done to ascertain the actual practices of the PCPs. These results could thus be subject to recall bias and overestimation/underestimation. Also, our outcome only reflected PCPs practising in an urban setting. Further studies would be needed to determine the knowledge and practices of CRC screening among PCPs in rural areas.

Our study revealed that fewer than $40 \%$ of PCPs were able to risk stratify CRC risk correctly. Mean knowledge score on CRC screening was about $50 \%$ and was positively associated with having a postgraduate educational qualification and the usage of guidelines. The practice of screening was low in our study when compared to other countries. Educating PCPs with the latest evidence and guidelines will ensure that the right recommendations for screening are provided to patients. However, having knowledge does not necessarily translate into practice. Agreement that screening was cost-effective and having adequate resources for screening were shown to have a positive association with the practice of screening. Therefore, measures to further educate PCPs regarding the cost-effectiveness of screening and the provision of adequate resources need to be undertaken to further increase its practice in Malaysia. These measures can also be explored further when planning population-based CRC screening in the future.

\section{ACKNOWLEDGEMENTS}

We would like to thank the Director General of Health, Malaysia, for his permission to publish this article and the staff at all the health clinics in Kuala Lumpur, Malaysia, for their support and participation in the study. This research was funded by the Postgraduate Research Fund (PPP) of University of Malaya, Malaysia (no. 2143/2014A).

\section{REFERENCES}

1. Ferlay J, Shin HR, Bray F, et al. Estimates of worldwide burden of cancer in 2008: GLOBOCAN 2008. Int J Cancer 2010; 127:2893-917.

2. Azizah Ab M, Nor Salleh IT, Noor Hashimah A, Asmah ZA, Mastulu W. Malaysian National Cancer Registry Report 2007-2011. Malaysian cancer statistics, data and figure. Available at: https://www.crc.gov.my/wp-content/uploads/documents/ report/MNCRRrepor2007-2011.pdf. Accessed May 25, 2017.

3. Winawer SJ, Zauber AG, Ho MN, et al. Prevention of colorectal cancer by colonoscopic polypectomy. The National Polyp Study Workgroup. N Engl J Med 1993; 329:1977-81.

4. Levin B, Lieberman D, McFarland B, et al; American Cancer Society Colorectal Cancer Advisory Group; US Multi-Society Task Force; American College of Radiology Colon Cancer Committee. Screening and surveillance for the early detection of colorectal cancer and adenomatous polyps, 2008: a joint guideline from the American Cancer Society, the US Multi-Society Task Force on Colorectal Cancer, and the American College of Radiology. Gastroenterology 2008; 134:1570-95.

5. Lee KJ, Inoue M, Otani T, et al; Japan Public Health Center-based Prospective Study. Colorectal cancer screening using fecal occult blood test and subsequent risk of colorectal cancer: a prospective cohort study in Japan. Cancer Detect Prev 2007; 31:3-11

6. Edwards $\mathrm{BK}$, Ward $\mathrm{E}$, Kohler BA, et al. Annual report to the nation on the status of cancer, 1975-2006, featuring colorectal cancer trends and impact of interventions (risk factors, screening, and treatment) to reduce future rates. Cancer 2010; 116:544-73.

7. Koo JH, Leong RW, Ching J, et al; Asia Pacific Working Group in Colorectal Cancer. Knowledge of, attitudes toward, and barriers to participation of colorectal cancer screening tests in the Asia-Pacific region: a multicenter study. Gastrointest Endosc 2012; 76:126-35.

8. Shapiro JA, Seeff LC, Thompson TD, et al. Colorectal cancer test use from the 2005 National Health Interview Survey. Cancer Epidemiol Biomarkers Prev 2008; 17:1623-30.

9. Syful Azlie MF, Hassan MR, Junainah S, Rugayah B. Immunochemical faecal occult blood test for colorectal cancer screening: a systematic review. Med J Malaysia 2015; 70:24-30.

10. Lim KG. A review of colorectal cancer research in Malaysia. Med J Malaysia 2014; 69 Suppl A:23-32.

11. Subramanian S, Klosterman M, Amonkar MM, Hunt TL. Adherence with colorectal cancer screening guidelines: a review. Prev Med 2004; 38:536-50.

12. Yusoff HM, Daud N, Noor NM, Rahim AA. Participation and barriers to colorectal cancer screening in Malaysia. Asian Pac J Cancer Prev 2012; 13:3983-7.

13. Klabunde C, Frame P, Meadow A, et al. A national survey of primary care physicians' colorectal cancer screening recommendations and practices. Prev Med 2003; 36:352-62.

14. McGregor SE, Hilsden RJ, Murray A, Bryant HE. Colorectal cancer screening: practices and opinions of primary care physicians. Prev Med 2004; 39:279-85.

15. Lemon SC, Zapka JG, Estabrook B, Erban S, Luckmann R. Screening for colorectal cancer on the front line. Am J Gastroenterol 2003; 98:915-23.

16. Ministry of Health, Singapore. Cancer Screening. MOH Clinical Practice Guidelines 1/2010. Available at: https://www.moh.gov.sg/content/dam/ moh_web/HPP/Doctors/cpg_medical/withdrawn/cpg_Cancer\%20Screening. pdf. Accessed May 25, 2017.

17. Schroy PC 3rd, Barrison AF, Ling BS, Wilson S, Geller AC. Family history and colorectal cancer screening: a survey of physician knowledge and practice patterns. Am J Gastroenterol 2002; 97:1031-6.

18. Yabroff KR, Klabunde CN, Yuan G, et al. Are physicians' recommendations for colorectal cancer screening guideline-consistent? J Gen Intern Med 2011; 26:177-84

19. White PM, Sahu M, Poles MA, Francois F. Colorectal cancer screening of highrisk populations: a national survey of physicians. BMC Res Notes 2012; 5:64. 
20. Federici A, Giorgi Rossi P, Bartolozzi F, et al. Survey on colorectal cance screening knowledge, attitudes, and practices of general practice physician in Lazio, Italy. Prev Med 2005; 41:30-5.

21. Klabunde CN, Lanier D, Nadel MR, et al. Colorectal cancer screening by primary care physicians: recommendations and practices, 2006-2007. Am J Prev Med 2009; 37:8-16.

22. Norwati D, Harmy MY, Norhayati MN, Amry AR. Colorectal cancer screening practices of primary care providers: results of a national survey in Malaysia. Asian Pac J Cancer Prev 2014; 15:2901-4.
23. Qureshi MA, Raj M, Ong KT, et al. Screening for colorectal cancer in Malaysia consensus/clinical practice guideline. Available at: http://www.acadmed.org. my/view_file.cfm?fileid=209. Accessed May 25, 2017.

24. Wong MC, Lam AT, Li DK, et al. Factors associated with practice of colorectal cancer screening among primary care physicians in a Chinese population: a cross-sectional study. Cancer Epidemiol 2009; 33:201-6.

25. Maciosek MV, Solberg LI, Coffield AB, Edwards NM, Goodman MJ. Colorectal cancer screening: health impact and cost effectiveness. Am J Prev Med 2006; $31: 80-9$ 


\section{APPENDIX}

\section{Questionnaire}

A. Demographic Data and Practice

Please tick accordingly
1. Gender:
$\square$ Male
Female
2. Age:
3. Ethnicity:
$\square$ Malay $\square$ Chinese
$\square$ Indian
Others (please state):

4. Do you have any postgraduate qualifications?
$\square$ Yes (Please state:
） $\square$ No

5. Years of practice as a doctor in outpatient setting:

6. On average, how many patients do you see in a day?
$\square \leq 20$
$\square 21-40$
$\square 41-60$
$61-80$
$81-100$
$>100$

7. Which clinic are you working in currently?

\begin{tabular}{|lll|}
\hline$\square$ KK KG PANDAN & $\square$ KK JINJANG & $\square$ KK CHERAS BARU \\
\hline$\square$ KK DATO KERAMAT & $\square$ KK SENTUL & $\square$ KK TANGLIN \\
\hline$\square$ KK PETALING BAHAGIA & $\square$ KK BATU & $\square$ KK SETAPAK \\
\hline$\square$ KK KUALA LUMPUR & $\square$ KK BTR & $\square$ RUKA UMMC \\
\hline$\square$ KK CHERAS & $\square$ KK SG BESI & $\square$ PUSAT PERUBATAN PRIMER HUKM \\
\hline
\end{tabular}

8. Currently, there are many guidelines for colorectal cancer screening. Which colorectal cancer screening guidelines are you using in your practice?

$\square \quad$ US Preventive Service Task Force recommendations

$\square \quad$ Asia Pacific consensus recommendations for colorectal cancer screening

$\square \quad$ European guidelines for quality assurance in colorectal cancer screening and diagnosis

$\square \quad$ American College of Physician

$\square \quad$ American College of Gastroenterology

$\square \quad$ Singapore Cancer Screening Guidelines

$\square \quad$ Others (please specify):

$\square \quad$ I am not using any guidelines

\section{B. Risk Stratification of Colorectal Cancer}

Below are 4 clinical scenarios. Please assess the lifetime risk of colorectal cancer for each clinical scenario. The patients are asymptomatic. Please tick one answer only.

\begin{tabular}{|lll|}
\hline \multicolumn{1}{|c|}{ Scenario } & Estimated lifetime risk \\
\hline 1. & Patient, age 62, with history of & $\square$ High \\
& inflammatory bowel disease. & $\square$ Average \\
& & $\square$ Low \\
& & $\square$ Don't know \\
\hline 2. & Patient, age 60, with family & $\square$ High \\
& history of colorectal cancer in two & $\square$ Average \\
& relatives (one at age 45, one age & $\square$ Low \\
& at 50). & $\square$ Don't know \\
\hline 3. & Female, age 60, no family history of & $\square$ High \\
& colorectal cancer. & $\square$ Average \\
& & $\square$ Low \\
& & $\square$ Don't know \\
\hline 4. & $\square$ High \\
& colorectal cancer. & $\square$ Average \\
& & $\square$ Low \\
&
\end{tabular}




\section{Knowledge on Colorectal Cancer Screening Modalities}

1. For patients who are asymptomatic who are average risk for colorectal cancer, please complete the table below based on the current recommendations for colorectal cancer screening.

If your answer is no or don't know for the question in the first column, you do not need to answer the following columns.

\begin{tabular}{|c|c|c|}
\hline Is the following test recommended? & Recommended starting age & Recommended frequency of testing (Please tick one) \\
\hline $\begin{array}{l}\text { Faecal occult blood test (FOBT) } \\
\square \text { Yes } \longrightarrow \\
\square \text { No } \\
\square \text { Don't know }\end{array}$ & $\ldots$ years old & $\begin{array}{l}\square \text { Every year } \\
\square \text { Every } 5 \text { years } \\
\square \text { Every } 10 \text { years }\end{array}$ \\
\hline $\begin{array}{l}\text { Colonoscopy } \\
\square \text { Yes } \longrightarrow \\
\square \text { No } \\
\square \text { Don't know }\end{array}$ & years old & $\begin{array}{l}\square \text { Every year } \\
\square \text { Every } 3 \text { years } \\
\square \text { Every } 10 \text { years }\end{array}$ \\
\hline $\begin{array}{l}\text { Double-contrast barium enema (DCBE) } \\
\square \text { Yes } \longrightarrow \\
\square \text { No } \\
\square \text { Don't know }\end{array}$ & _ years old & $\begin{array}{l}\square \text { Every year } \\
\square \text { Every } 5 \text { years } \\
\square \text { Every } 10 \text { years }\end{array}$ \\
\hline $\begin{array}{l}\text { Flexible sigmoidosopy } \\
\square \text { Yes } \longrightarrow \\
\square \text { No } \\
\square \text { Don't know }\end{array}$ & years old & $\begin{array}{l}\square \text { Every year } \\
\square \text { Every } 5 \text { years } \\
\square \text { Every } 10 \text { years }\end{array}$ \\
\hline $\begin{array}{l}\text { Serum carcinoembryonic antigen (CEA) } \\
\square \text { Yes } \longrightarrow \\
\square \text { No } \\
\square \text { Don't know }\end{array}$ & ____ years old & $\begin{array}{l}\square \text { Every year } \\
\square \text { Every } 3 \text { years } \\
\square \text { Every } 10 \text { years }\end{array}$ \\
\hline
\end{tabular}

2. For patients who are asymptomatic, please complete the table below based on the current recommendations for colorectal cancer screening. If your answer is no or don't know for the question in the first column, you do not need to answer the following columns.

\begin{tabular}{|c|c|c|c|}
\hline $\begin{array}{l}\text { Is screening recommended for the } \\
\text { following condition? }\end{array}$ & $\begin{array}{l}\text { Recommended } \\
\text { starting age }\end{array}$ & $\begin{array}{l}\text { Recommended } \\
\text { frequency of testing }\end{array}$ & $\begin{array}{l}\text { Recommended test (you may tick } \\
\text { as many as you want) }\end{array}$ \\
\hline $\begin{array}{l}\text { Family history of familial adenomatous } \\
\text { polyposis } \\
\square \text { Yes } \\
\square \text { No } \\
\square \text { Don't know }\end{array}$ & & $\begin{array}{l}\square \text { Every year } \\
\square \text { Every } 3 \text { years } \\
\square \text { Every } 10 \text { years }\end{array}$ & $\begin{array}{l}\square \text { Colonoscopy } \\
\square \text { FOBT } \\
\square \text { Double contrast barium enema } \\
\square \text { Serum CEA } \\
\square \text { Flexible sigmoidoscopy } \\
\square \text { Genetic testing }\end{array}$ \\
\hline $\begin{array}{l}\text { Family history of hereditary } \\
\text { non-polyposis colorectal cancer } \\
\square \text { Yes } \\
\square \text { No } \\
\square \text { Don't know }\end{array}$ & 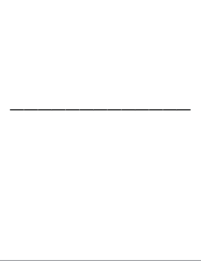 & $\begin{array}{l}\square \text { Every year } \\
\square \text { Every } 3 \text { years } \\
\square \text { Every } 10 \text { years }\end{array}$ & $\begin{array}{l}\square \text { Colonoscopy } \\
\square \text { FOBT } \\
\square \text { Double contrast barium enema } \\
\square \text { Serum CEA } \\
\square \text { Flexible sigmoidoscopy } \\
\square \text { Genetic testing }\end{array}$ \\
\hline $\begin{array}{l}\text { Patient with inflammatory bowel } \\
\text { disease* } \\
\square \text { Yes } \\
\square \text { No } \\
\square \text { Don't know }\end{array}$ & 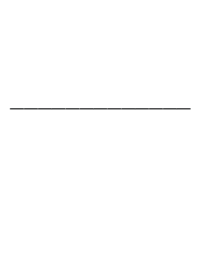 & $\begin{array}{l}\square \text { Every year } \\
\square \text { Every } 3 \text { years } \\
\square \text { Every } 10 \text { years }\end{array}$ & $\begin{array}{l}\square \text { Colonoscopy } \\
\square \text { FOBT } \\
\square \text { Double contrast barium enema } \\
\square \text { Serum CEA } \\
\square \text { Flexible sigmoidoscopy } \\
\square \text { Genetic testing }\end{array}$ \\
\hline
\end{tabular}




\section{Practice of Colorectal Cancer Screening}

Please complete the questions below based on your practice on asymptomatic patients (in good health for their age without risk factors) for colorectal cancer screening. Please respond based on how you actually practise even if this differs from how you would like to practise under ideal circumstances.

1. Do you screen patients for colorectal cancer in your practice? (If your answer is $\underline{\text { No}}$, please proceed to $\underline{\text { Section } \mathbf{E}}$ ).
$\square$ Yes
$\square$ No

2. At what age of the patient do you start offering colorectal cancer screening?

3. To what proportion of your patients who have reached this age (as stated in Question 2) do you offer colorectal cancer screening?
$\square \leq 25 \%$
$\square 26 \%-49 \%$
$\square 50 \%-74 \%$
$\square \geq 75 \%$

4. Please rank in order based on your usual practice the type of colorectal cancer screening test most often used. ( $1=$ most often used,

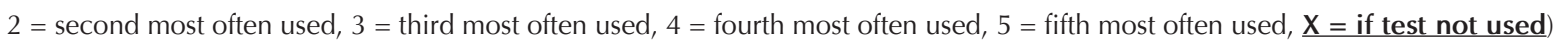

\begin{tabular}{|c|c|}
\hline Screening test & Rank \\
\hline Serum carcinoembryonic antigen & \\
\hline Colonoscopy & \\
\hline Double contrast barium enema & \\
\hline Faecal occult blood test & \\
\hline Flexible sigmoidoscopy & \\
\hline
\end{tabular}

E. Perceived barriers and facilitators influencing decision for colorectal cancer screening

Please indicate how much you agree or disagree with the following statements (Please tick one).

\begin{tabular}{|c|c|c|c|c|c|}
\hline Question & $\begin{array}{l}\text { Strongly } \\
\text { agree }\end{array}$ & Agree & Disagree & $\begin{array}{l}\text { Strongly } \\
\text { disagree }\end{array}$ & $\begin{array}{l}\text { Not } \\
\text { sure }\end{array}$ \\
\hline \multicolumn{6}{|l|}{ I have enough knowledge about the various colorectal cancer screening tests. } \\
\hline \multicolumn{6}{|l|}{ Recommendations about colorectal cancer screening are inconsistent. } \\
\hline \multicolumn{6}{|l|}{ Screening for colorectal cancer is cost-effective. } \\
\hline \multicolumn{6}{|l|}{$\begin{array}{l}\text { Time restrictions during a routine check-up mean other conditions (e.g. heart disease) } \\
\text { have higher priority than screening for colorectal cancer. }\end{array}$} \\
\hline \multicolumn{6}{|l|}{ Screening for colorectal cancer is beneficial for my patients. } \\
\hline $\begin{array}{l}\text { There are adequate laboratory, diagnostic, and specialist resources in my health region } \\
\text { for the implementation of colorectal screening. }\end{array}$ & & & & & \\
\hline
\end{tabular}

